\title{
Prevalence of undernutrition among tribal adolescents of Karbi Anglong district of Assam, Northeast India
}

\author{
Nitish Mondal ${ }^{1}$, Moloya Terangpi ${ }^{2}$ \\ Sri Lanka Journal of Child Health, 2014; 43(3): 154-157
}

\begin{abstract}
Background: Undernutrition is a major public health problem affecting children and adolescents of developing countries such as India and causes high mortality and morbidity.
\end{abstract}

Objective: To assess prevalence of undernutrition among tribal adolescents of Karbi Anglong district of Assam, Northeast India

Method: A cross-sectional study was carried out among 864 (448 boys) tribal adolescents aged 1017 years of Karbi Anglong district of Assam, Northeast India. Height and weight were recorded and the body mass index calculated. WHO recommended indices of stunting (height-for-age, $<3^{\text {rd }}$ percentile of National Centre of Health Statistics) and thinness (BMI-for-age, $<5^{\text {th }}$ percentile, National Health and Nutrition Examination Survey) were used to assess the prevalence of undernutrition.

Results: Overall mean height, weight and BMI were found to be significantly higher among boys than girls $(\mathrm{p}<0.05)$. Age specific mean BMI values ranged from $16.8 \mathrm{~kg} / \mathrm{m}^{2}$ to $20.1 \mathrm{~kg} / \mathrm{m}^{2}$ in boys and $15.1 \mathrm{~kg} / \mathrm{m}^{2}$ to $18.7 \mathrm{~kg} / \mathrm{m}^{2}$ in girls $10-17$ years old. Overall prevalence of stunting $(51.2 \%)$ was found markedly higher than thinness (13.4\%). Sexspecific overall stunting was similar among girls $(50.2 \%)$ and boys $(50.1 \%)$. Overall prevalence of thinness was slightly higher among girls (14.9\%) than boys $(12.05 \%)(\mathrm{p}>0.05)$.

Conclusion: Stunting was present in $51.2 \%$ and thinness in $13.4 \%$ among tribal adolescents of Karbi Anglong district of Assam, Northeast India.

(Keywords: Stunting; thinness; BMI; adolescents; anthropometry)

\section{Introduction}

Prevalence of undernutrition continues to be the

${ }^{1}$ Assistant Professor, ${ }^{2}$ Ex-Postgraduate Student, Department of Anthropology, Assam University: Diphu Campus, Karbi Anglong, Assam, India
(Received on 13 November 2013: Accepted after revision on 09 January 2014)

principal cause of ill-health, premature mortality and morbidity in developing countries ${ }^{1,2}$. Nutritional studies have highlighted that prevalence of chronic energy deficiency (CED) is still a major public health problem in Indian populations , $^{1,3-5}$. Prevalence of CED was high due to immense population size, socioeconomic disparities, illiteracy and inadequate access to basic healthcare facilities $^{6-7}$. Anthropometry is a non-invasive and inexpensive practical technique of nutritional assessment especially in nutritional and epidemiological investigations ${ }^{8}$. Stunting (low height for age), thinness (low body mass index for age), wasting (low weight for height) and underweight (low weight for age) are commonly used to assess the nutritional status among children and adolescents ${ }^{1,5,8}$. Adolescents comprise a significantly large population cohort of 243 million (20\%) aged 10-19 years in India ${ }^{9}$. Growth and nutritional status of adolescents are markedly unsatisfactory among Indian populations ${ }^{2-5,10-18}$. Nutritional status of adolescent girls contributes significantly to overall nutritional status, reproductive performance and work capacity ${ }^{8,10,13}$.

\section{Objective}

To assess the prevalence of undernutrition among tribal adolescents of Karbi Anglong district of Assam, Northeast India

\section{Method}

A cross-sectional study was carried out among 864 tribal adolescents aged 10-17 years of Karbi Anglong district of Assam, Northeast India. Ethnically Karbis belong to the Tibeto-Burman speaking group ${ }^{19}$. Of 960 subjects identified in the 10-17 year age group, 96 (56 boys; 40 girls) were excluded due to inappropriate age, absence or unwillingness to participate in study. The final sample size comprising 448 boys and 416 girls were included using the multistage stratified sampling method. Ages of subjects were recorded from school records and subsequently verified from their birth certificates and official documents. A structured schedule was utilized to obtain the necessary data on age, sex, family income, education, occupation, family size and physical 
exercise. Subjects of present study belong to the agricultural and manual and/or skilled labour group family background.

Modified scale of Kuppuswamy was utilized to ascertain the socioeconomic status of the children $^{20}$. Based on above-mentioned scale, subjects belonged to the lower to middle socioeconomic group. Present investigation was done by conducting household surveys and school visits. Anthropometric and socioeconomic data were collected from November 2011 to September 2012. Permission was obtained from the schools and the village level authorities prior to conducting the investigation. Verbal consent was also taken from each subject and their parents prior to obtaining data. All individuals were free from any postsurgical episodes or physical deformities and were not suffering from any systemic diseases at the time of data collection. Investigation was conducted in accordance with the ethical guidelines of human experiments as laid down in the Helsinki Declaration $^{21}$

Collection of anthropometric data: Heights and weights were recorded using standard procedures ${ }^{22}$. Height was taken with the help of an anthropometer rod to the nearest $0.1 \mathrm{~cm}$. Subject stood erect and head was oriented in the Frankfort horizontal plane. Weight was recorded to the nearest $0.1 \mathrm{~kg}$ using the portable weighing machine, subjects wearing minimum clothing. Body mass index (BMI) was calculated using the standard equation ${ }^{8}$ : BMI $\left(\mathrm{kg} / \mathrm{m}^{2}\right)=$ weight $(\mathrm{kg})$ /height $\left(\mathrm{m}^{2}\right)$. Technical error measurement $\left\{\mathrm{TEM}=\sqrt{ }\left(\Sigma \mathrm{D}^{2} / 2 \mathrm{~N}\right), \mathrm{D}=\right.$ difference between the measurements, $\mathrm{N}=$ number of individuals measured $\}$ was calculated following the standard method $^{23}$ and coefficient of reliability $[R=\{1-$ $\left.(\mathrm{TEM})^{2} / \mathrm{SD}^{2}\right\}, \mathrm{SD}=$ standard deviation of all measurements] of anthropometric measurements were calculated for testing reliability of the measurements ${ }^{23}$. To determine the intra- and interobserver accuracy of measurements using TEM, height and weight were recorded from 30 children by both authors. Very high values $(>0.980)$ of $R$ were obtained for height and weight, and these values were found within the cut-off of 0.950 as suggested by Ulijaszek and $\mathrm{Kerr}^{23}$. Hence the measurements obtained in present study were reliable and reproducible and TEM was not incorporated in further statistical consideration.

Assessment of nutritional status: Recommended anthropometric indices have been utilized to assess the nutritional status among adolescents ${ }^{8}$. Low height-for-age measures linear growth retardation and primarily reflects chronic undernutrition. Height-for-age below $3^{\text {rd }}$ percentile of the National Centre for Health Statistics (NCHS) reference values was classified as stunting ${ }^{8,24}$. Thinness (low BMI-for-age) was assessed by comparing age- and sex-specific recommended cut-off values of Nutritional Health and Nutritional Examination Survey (NHANES). BMI-for-age below the 5th percentile of NHANES values was classified as thinness or $\mathrm{CED}^{8}$.

Data was statistically analysed utilizing the Statistical Package for Social Sciences (SPSS, version 16.0). Collected anthropometric variables were depicted using descriptive statistics of mean and standard deviation. One-way analysis of variance (ANOVA) was done to assess the mean difference between sexes and age groups. Chisquare analysis was utilized to assess the differences in overall and age specific prevalence. Yates correction was taken into consideration in $x^{2}$ tests where cells possessed less than five individuals. The differences were considered to be statistically significant at $\mathrm{p}<0.05$ level.

\section{Results}

Age- and sex-specific subject distribution, descriptive of height, weight, BMI and prevalence of undernutrition among the Karbi adolescents is depicted in Table 1. Age specific mean values in height, weight and BMI gradually increased with age among boys and girls, the only exception being in BMI among 16 years (in boys) and 15 years (in girls). Overall mean height, weight and BMI were found significantly higher among boys than girls. Sex differences were found statistically significant in weight $(\mathrm{F}$ value $=54.41$; df 1,863$)$, height $(\mathrm{F}$ value $=23.84$; df 1,863$)$ and $\mathrm{BMI}(\mathrm{F}$ value $=47.00$; df 1,863$)$ using ANOVA $(\mathrm{p}<0.01)$. Age specific mean BMI values ranged from $16.82 \mathrm{~kg} / \mathrm{m}^{2}$ to $20.05 \mathrm{~kg} / \mathrm{m}^{2}$ in boys and $15.05 \mathrm{~kg} / \mathrm{m}^{2}$ to 18.73 $\mathrm{kg} / \mathrm{m}^{2}$ in girls among 10 to 17 year olds. Using ANOVA, age specific mean differences in weight (F-value=108.91; df 7, 447 and $F$-value=91.34, df 1, 415), height $(\mathrm{F}$-value $=64.34$; df 7, 447 and $\mathrm{F}$ value $=73$. 56, df 1,415$)$ and $\mathrm{BMI}(\mathrm{F}-\mathrm{value}=88.76$; df 7, 447 and $F$-value=30.49, df 1, 415) were found to be statistically significantly among boys and girls $(\mathrm{p}<0.01)$.

The overall prevalence of stunting $(51.16 \%)$ was found markedly higher than thinness (13.43\%) among Karbi adolescents $(p<0.01)$ (Table 1). Sex specific overall prevalence of stunting was similar among girls (50.2\%) and boys (50.1\%) ( $\mathrm{p}>0.05)$. Age specific prevalence of stunting did not show any definite age related trend and stunting was found higher among 16 years $(71.05 \%)$ and 13 years $(74.60 \%)$ among boys and girls respectively. The age-wise prevalence of stunting ranged from $34.4 \%$ in 13 year olds to $64.0 \%$ in 16 year olds 
Table 1: Age \& sex distribution, (mean \pm SD) of weight, height and BMI \& prevalence of undernutrition among Karbi adolescents

\begin{tabular}{|c|c|c|c|c|c|c|c|c|c|c|c|c|}
\hline \multirow[t]{2}{*}{$\begin{array}{l}\text { Age } \\
\text { group }\end{array}$} & \multicolumn{2}{|c|}{ Number } & \multicolumn{2}{|c|}{ Weight (kg) } & \multicolumn{2}{|c|}{ Height (cm) } & \multicolumn{2}{|c|}{ BMI (kg/m2) } & \multicolumn{2}{|c|}{$\begin{array}{c}\text { Stunting } \\
\left(<3^{\text {rd }} \text { centile }\right. \\
\text { NCHS })\end{array}$} & \multicolumn{2}{|c|}{$\begin{array}{c}\text { Thinness } \\
\left(<5^{\text {th }} \text { centile }\right. \\
\text { NAHNES })\end{array}$} \\
\hline & Boys & Girls & Boys & Girls & Boys & Girls & Boys & Girls & Boys & Girls & Boys & Girls \\
\hline $\begin{array}{c}10 \\
\text { years }\end{array}$ & 42 & 37 & $\begin{array}{l}31.6 \\
\pm 7.3\end{array}$ & $\begin{array}{l}27.4 \\
\pm 4.4\end{array}$ & $\begin{array}{c}134.6 \\
\pm 5.1\end{array}$ & $\begin{array}{c}134.6 \\
\pm 5.1\end{array}$ & $\begin{array}{l}16.8 \\
\pm 3.5\end{array}$ & $\begin{array}{l}15.0 \\
\pm 2.0\end{array}$ & $\begin{array}{c}08 \\
(19.1)\end{array}$ & $\begin{array}{c}09 \\
(24.3)\end{array}$ & $\begin{array}{c}13 \\
(31.0)\end{array}$ & $\begin{array}{c}13 \\
(35.2) \\
\end{array}$ \\
\hline $\begin{array}{c}11 \\
\text { years }\end{array}$ & 40 & 35 & $\begin{array}{l}32.0 \\
\pm 5.4 \\
\end{array}$ & $\begin{array}{l}30.6 \\
\pm 4.5 \\
\end{array}$ & $\begin{array}{c}136.2 \\
\pm 6.5 \\
\end{array}$ & $\begin{array}{c}136.2 \\
\pm 6.5 \\
\end{array}$ & $\begin{array}{l}16.7 \\
\pm 1.3\end{array}$ & $\begin{array}{r}16.5 \\
\pm 1.8\end{array}$ & $\begin{array}{c}15 \\
(37.5)\end{array}$ & $\begin{array}{c}14 \\
(40.0)\end{array}$ & $\begin{array}{c}05 \\
(12.5)\end{array}$ & $\begin{array}{c}05 \\
(14.3)\end{array}$ \\
\hline $\begin{array}{c}12 \\
\text { years }\end{array}$ & 42 & 38 & $\begin{array}{l}35.2 \\
\pm 7.2 \\
\end{array}$ & $\begin{array}{l}34.2 \\
\pm 6.6 \\
\end{array}$ & $\begin{array}{c}141.1 \\
\pm 7.2 \\
\end{array}$ & $\begin{array}{c}141.1 \\
\pm 7.2 \\
\end{array}$ & $\begin{array}{l}17.1 \\
\pm 1.9 \\
\end{array}$ & $\begin{array}{r}17.1 \\
\pm 2.0 \\
\end{array}$ & $\begin{array}{c}14 \\
(33.3) \\
\end{array}$ & $\begin{array}{c}19 \\
(50.0)\end{array}$ & $\begin{array}{c}09 \\
(21.4)\end{array}$ & $\begin{array}{c}08 \\
(21.1) \\
\end{array}$ \\
\hline $\begin{array}{c}13 \\
\text { years }\end{array}$ & 56 & 63 & $\begin{array}{l}37.6 \\
\pm 5.5\end{array}$ & $\begin{array}{l}34.4 \\
\pm 4.5\end{array}$ & $\begin{array}{c}142.8 \\
\pm 5.9\end{array}$ & $\begin{array}{c}142.8 \\
\pm 5.9\end{array}$ & $\begin{array}{l}17.8 \\
\pm 1.4 \\
\end{array}$ & $\begin{array}{l}16.7 \\
\pm 1.6 \\
\end{array}$ & $\begin{array}{c}21 \\
(37.5)\end{array}$ & $\begin{array}{c}47 \\
(74.6)\end{array}$ & $\begin{array}{c}09 \\
(16.1)\end{array}$ & $\begin{array}{c}19 \\
(30.2)\end{array}$ \\
\hline $\begin{array}{c}14 \\
\text { years }\end{array}$ & 67 & 50 & $\begin{array}{l}41.3 \\
\pm 4.8\end{array}$ & $\begin{array}{l}37.8 \\
\pm 3.7\end{array}$ & $\begin{array}{c}145.7 \\
\pm 5.7\end{array}$ & $\begin{array}{c}145.7 \\
\pm 5.7\end{array}$ & $\begin{array}{l}18.4 \\
\pm 1.4\end{array}$ & $\begin{array}{r}17.8 \\
\pm 1.3\end{array}$ & $\begin{array}{c}34 \\
(50.7)\end{array}$ & $\begin{array}{c}37 \\
(74.0)\end{array}$ & $\begin{array}{c}10 \\
(14.9)\end{array}$ & $\begin{array}{c}03 \\
(06.0)\end{array}$ \\
\hline $\begin{array}{c}15 \\
\text { years }\end{array}$ & 57 & 70 & $\begin{array}{l}45.4 \\
\pm 3.7 \\
\end{array}$ & $\begin{array}{l}41.0 \\
\pm 3.5\end{array}$ & $\begin{array}{c}149.6 \\
\pm 4.3 \\
\end{array}$ & $\begin{array}{c}149.6 \\
\pm 4.3 \\
\end{array}$ & $\begin{array}{l}19.4 \\
\pm 1.3 \\
\end{array}$ & $\begin{array}{r}18.4 \\
\pm 1.4 \\
\end{array}$ & $\begin{array}{c}35 \\
(61.4)\end{array}$ & $\begin{array}{c}30 \\
(42.9)\end{array}$ & $\begin{array}{c}03 \\
(5.26)\end{array}$ & $\begin{array}{c}04 \\
(05.7) \\
\end{array}$ \\
\hline $\begin{array}{c}16 \\
\text { years }\end{array}$ & 76 & 65 & $\begin{array}{l}47.4 \\
\pm 3.4 \\
\end{array}$ & $\begin{array}{l}42.4 \\
\pm 3.5\end{array}$ & $\begin{array}{c}151.5 \\
\pm 5.4 \\
\end{array}$ & $\begin{array}{c}151.5 \\
\pm 5.4 \\
\end{array}$ & $\begin{array}{l}19.3 \\
\pm 2.5 \\
\end{array}$ & $\begin{array}{r}18.5 \\
\pm 1.3\end{array}$ & $\begin{array}{c}54 \\
(71.1)\end{array}$ & $\begin{array}{c}32 \\
(49.2)\end{array}$ & $\begin{array}{c}03 \\
(3.94)\end{array}$ & $\begin{array}{c}05 \\
(07.7) \\
\end{array}$ \\
\hline $\begin{array}{c}17 \\
\text { years }\end{array}$ & 68 & 58 & $\begin{array}{l}49.6 \\
\pm 2.1 \\
\end{array}$ & $\begin{array}{l}44.5 \\
\pm 4.1 \\
\end{array}$ & $\begin{array}{c}154.0 \\
\pm 5.5 \\
\end{array}$ & $\begin{array}{c}154.0 \\
\pm 5.5 \\
\end{array}$ & $\begin{array}{l}20.1 \\
\pm 0.8\end{array}$ & $\begin{array}{r}18.7 \\
\pm 1.3\end{array}$ & $\begin{array}{c}48 \\
(70.6)\end{array}$ & $\begin{array}{c}25 \\
(43.2)\end{array}$ & $\begin{array}{c}02 \\
(2.94)\end{array}$ & $\begin{array}{c}05 \\
(08.6)\end{array}$ \\
\hline Total & 448 & 416 & $\begin{array}{l}41.3 \\
\pm 8.0\end{array}$ & $\begin{array}{l}37.6 \\
\pm 6.8\end{array}$ & $\begin{array}{c}145.8 \\
\pm 8.4\end{array}$ & $\begin{array}{c}145.8 \\
\pm 8.4\end{array}$ & $\begin{array}{l}18.4 \\
\pm 2.2\end{array}$ & $\begin{array}{r}17.6 \\
\pm 1.9\end{array}$ & $\begin{array}{c}229 \\
(51.1)\end{array}$ & $\begin{array}{c}213 \\
(51.2)\end{array}$ & $\begin{array}{c}54 \\
(12.05)\end{array}$ & $\begin{array}{c}62 \\
(14.9) \\
\end{array}$ \\
\hline
\end{tabular}

Values in parenthesis indicates percentage

The sex differences in the age specific prevalence of stunting were found statistically not significant using Chi-square analysis $(\mathrm{p}>0.05)$ except in 13 year olds Chi-square value $=4.68 ; p<0.05$ ). Overall prevalence of thinness was slightly higher among girls $(14.90 \%)$ than boys $(12.05 \%)(\mathrm{p}>0.05)$. Age specific prevalence of thinness did not show any general trend, but prevalence was found to be higher in early ages (10-13 years). Age specific prevalence of thinness was higher among the boys $(30.95 \%)$ and girls $(35.16 \%)$ aged 10 years. Age specific difference in thinness among boys and girls was not found to be statistically significant using Chi-square analysis ( $\mathrm{p}>0.05)$.

\section{Discussion}

Prevalence of stunting measures overall social deprivation that is considered a legacy of prolonged nutritional deprivation during childhood $^{3-4,8,13}$. Present study showed a high prevalence of stunting among adolescents probably due to long term nutritional deprivation and poor socioeconomic conditions during early childhood. Several researchers have reported prevalence of early nutritional deprivation among Indian adolescents $^{2,4,12,13}$. Prevalence of undernutrition was found to be greatest among children and adolescents belonging to lower as compared to higher socioeconomic groups in India ${ }^{2,4,13}$. Present study has reported overall prevalence of stunting and thinness to be $51.2 \%$ and $13.4 \%$ among Karbi adolescents respectively. Prevalence of stunting was similar to studies reported among adolescents of tea garden worker of Assam $(53.6 \%)^{12}$, Nalgonda, Andhra Pradesh (47\%) ${ }^{25}$, Dibrugarh, Assam $(45.5 \%)^{13}$ and Darjeeling, West Bengal $(46.6 \%)^{4}$. When, the sex specific prevalence of stunting was considered, prevalence was slightly higher among girls than boys $(p>0.05)$. Medhi et al. ${ }^{13}$ have reported very high prevalence of stunting (50\% boys; $43 \%$ girls) among adolescents of Assam, Northeast India. A high prevalence of stunting $(52.5 \%)$ has also been reported in West Bengal ${ }^{15}$. Deshmukh et al. ${ }^{2}$ reported a similar prevalence of stunting $(50.7 \%)$ from rural Wardha. Utilizing data from the National Nutrition Monitoring Bureau (NNMB), Venkaiah et al. ${ }^{10}$ reported about $39 \%$ of rural adolescents to be stunted. A high prevalence of stunting was also found among boys (43\%) and girls (50.3\%) of Darjeeling, West Bengal ${ }^{4}$. A lower prevalence of stunting was reported by Anand et al. ${ }^{26}$ (38.5\%), Malhotra and $\mathrm{Passi}^{27}$ (29.7\%) in North India.

Prevalence of thinness was found to be significantly $(p>0.01)$ lower than the reported studies among Indian adolescents. Sex specific prevalence of thinness was found insignificantly higher among girls than boys $(p>0.05)$. Prevalence of thinness was found to be higher in the early age groups (10-13 years), but decreased with age. A similar trend has been reported among adolescents $^{5,13}$. It has also been observed that 
adolescent boys were more sufferers than girls $(59.4 \%$ versus $41.3 \%)$ in Assam $^{13}$. Rao et al. ${ }^{11}$ utilizing the NNMB data reported the prevalence of thinness among tribal adolescent boys (63\%) and girls $(42 \%)$ among nine Indian states. Venkaiah et al. ${ }^{10}$ also reported prevalence of thinness to be higher in boys (53\%) than girls (39.5\%). Similarly, a higher prevalence of thinness was found among boys (53\%) than girls (32\%) among rural adolescents of Darjeeling, West Bengal. A lower prevalence of thinness among adolescents has been reported in North India $(30.6 \%)^{27}$, Nalgonda, Andhra Pradesh $(20.60 \%)^{25}$ and Paschim Medinipur, West Bengal $(20.23 \%)^{18}$.

The present investigation showed that the rural Karbi adolescents are facing a great risk in terms of nutritional stress (e.g. stunting) which is more pronounced in both sexes. The magnitude of stunting is considered to be still a major problem than thinness. The poor nutritional status among adolescents, particularly girls, has important implications in terms of physical work capacity and adverse reproductive outcomes ${ }^{8,10,26}$. The adolescent suffering from stunting and thinness in early periods will develop obesity and CED during adulthood respectively, that would have an impact on their work productivity and lead to greater prevalence of morbidity and mortality as well ${ }^{8,28}$.

\section{References}

1. Nandy S, Irving M, Gordon D, Subramanian SV, Smith GD. Poverty, child undernutrition and morbidity: New evidence from India. Bulletin of World Health Organization 2005; 83(3): 210-6.

2. Deshmukh, PR, Gupta SS, Bharambe MS, Dongre AR, Maliye C, Kaur S, et al. Nutritional status of adolescents in rural Wardha. Indian Journal of Pediatrics 2006; 73(2):139-41.

http://dx.doi.org/10.1007/BF02820204

3. Mondal N, Sen J. Prevalence of undernutrition among children (5-12 years) belonging to three communities residing in a similar habitat in North Bengal, India. Annals of Human Biology 2010; 37(2): 198-216. http://dx.doi.org/10.3109/03014460903341844

4. Mondal N, Sen J. Prevalence of stunting and thinness among rural adolescents of Darjeeling district, West Bengal, India. Italian Journal Public Health 2010; 7(1): 54-61.

5. Sen J, Mondal N. Socio-economic and demographic factors affecting the Composite
Index of Anthropometric Failure (CIAF). Annals of Human Biology 2012; 39(2):129-36. http://dx.doi.org/10.3109/03014460.2012.6557 $\underline{77}$

6. Antony GM, Laxmaiah A. Human development, poverty, health \& nutrition situation in India. Indian Journal of Medical Research 2008; 128(2): 198-205.

7. Parasuraman S, Kishor S, Singh SK, Y Vaidehi . A profile of youth in India. National Family Health Survey (NFHS-3), India, 200506. Mumbai: International Institute for Population Sciences, Calverton, Maryland, USA: ICF Macro, 2009.

8. World Health Organization. Physical Status: The use and interpretation of anthropometry. Technical Report Series No. 854, Geneva: World Health Organization, 1995.

9. United Nation Children's Fund (UNICEF). The state of the world's children 2011: Adolescence, an age of opportunity, New York: UNICEF, 2011.

10. Venkaiah K, Damayanti K, Nayak MU, Vijayaraghavan K. Diet and nutritional status of rural adolescents in India. European Journal of Clinical Nutrition 2002; 56(11): 1119-25. http://dx.doi.org/10.1038/sj.ejen.1601457

11. Rao K. Balakrishna MN, Laxmaiah A, Venkaiah K, Brahmam GN. Diet and nutritional status of adolescent tribal population in nine States of India Asia Pacific Journal of Clinical Nutrition 2006; 15(1): 6471.

12. Medhi G K, Barua A, Mahanta J. Growth and nutritional status of school age children (6-14 Years) of tea garden workers of Assam. Journal of Human Ecology 2006; 19(2): 83-85.

13. Medhi G K, Hazarika NC, Mahanta J. Nutritional status of adolescents among tea garden workers. Indian Journal of Paediatrics 2007; 74(4): 343-7. http://dx.doi.org/10.1007/s12098-007-0057-3

14. Das BK, Bisai S. Prevalence of undernutrition among Telaga adolescents: An endogamous population of India. The Internet Journal of Biological Anthropology 2009; 2(2): DOI: 10.5580/c2b. Available from: http://ispub.com/IJBA/2/2/6141. 
http://dx.doi.org/10.5580/c2b

15. Das P, Ray SK, Joardar GK, Dasgupta S. Nutritional profiles of adolescents in a rural community of Hooghly district in West Bengal. Indian Journal of Public Health 2007; 51(2): 120-1

16. Bisai SK, Bose D, Ghosh De K. Growth pattern and prevalence of underweight and stunting among rural adolescents. Journal of Nepal Paediatric Society 2011; 31(1):17-24. http://dx.doi.org/10.3126/jnps.v31i1.3640

17. Maiti S, Ali KM, De D, Bera TK, Ghosh D, Paul S.. A comparative study on nutritional status of urban and rural early adolescent schoolgirls of West Bengal, India. Journal of Nepal Paediatric Society 2011; 31(3): 169-74. http://dx.doi.org/10.3126/jnps.v31i3.5352

18. Maiti SD, Chatterjee K, Jana K, Ghosh D, Paul S. Prevalence of stunting and thinness among early adolescent school girls of Paschim Medinipur district, West Bengal. International Journal of Biological and Medical Research 2011; 2(3): 781-3.

19. Das BM. Ethnic element in North East India. In S. Sengupta (eds): Peoples of North East India. New Delhi: Gyan Publishing House. 2011.

20. Mishra D, Singh HP. 2003. Kuppuswami's socio-economic status scale: A revision. Indian Journal of Pediatrics 2003; 70(3): 273-4. http://dx.doi.org/10.1007/BF02725598

21. Touitou Y, Portaluppi F, Smolensky MH, Rensing L. Ethical principles and standards for the conduct of human and animal biological rhythm research. Chronobiology international 2004; 21(1):161-70. http://dx.doi.org/10.1081/CBI-120030045

22. Weiner JS, Lourie JA. Practical Human Biology. London: Academic Press, 1981.

23. Ulijaszek SJ, Kerr DA. Anthropometric measurement error and the assessment of nutritional status British Journal of Nutrition 1999; 82(3): 165-77. http://dx.doi.org/10.1017/S0007114599001348

24. World Health Organization. Measuring Change in Nutritional Status. Geneva: World Health Organisation. 1983.

25. Prashant K, Shaw C. Nutritional status of adolescent girls from an urban slum area in South India. Indian Journal of Pediatrics 2009; 76(5): 501-4. http://dx.doi.org/10.1007/s12098-009-0077-2

26. Anand K, Kant S, Kapoor SK. Nutrition status of adolescent school children in rural North India. Indian Pediatrics 1999; 36(8): 810-5.

27. Malhotra A, Passi SJ. Diet quality and nutritional status of rural adolescent girl beneficiaries of ICDS in North India. Asia Pacific Journal of Clinical Nutrition 2007; 16(S1): 8-16.

28. Strickland SS. Functional consequences of adult malnutrition in developing countries: a review. Journal of Physiological Anthropology and Applied Human Science 2002; 21(1): 1-9. http://dx.doi.org/10.2114/jpa.21.1 